\title{
Reflections on College Students' Energy Security Awareness Education in the New Era of Innovation Research and Analysis
}

\author{
Xiaojun Zhang*, Hongxin Zhang and Honglei Jiao
}

Hebei Normal University of Science \& Technology, Qin Huang Dao, Hebei, 066004, China

\begin{abstract}
Nowadays, the concept and connotation of energy security has also undergone major changes. Traditionally, the energy security refers to the paid sufficient energy supply for affordable price. Considering the new situation of the changes of energy security, energy security includes the following six aspects. First, the material security; second, energy access is the key, whether it is physical, or the contract, or commercial development and the ability to obtain the energy supply; third, energy security is a system or system by the national policy and the international mechanism, maintain the stability of energy supply; fourth, energy security is closely related with the safety investment, the need for adequate policy support and safe business environment; fifth, energy security and climate change and environmental safety issues closely related; sixth, energy security is not limited to oil supply and oil security. Energy security is an important guarantee of national economic security, directly affect the national security, social stability and the sustainable development. This paper analyzes many problems with the new era of college students the importance of the issue of energy security energy security concept of education, and the concept of energy security problems of education, expounds the necessity and urgency of strengthening energy security education, combined with the actual source of College Students' safety education, put forward the energy security education. Combined with the education of Ideological and political education, professional education, humanistic spirit and scientific spirit education combining the specific countermeasures of innovation of College Students' education on the concept of energy security.
\end{abstract}

Keywords: College students, education innovation, energy security, Petroleum University.

\section{INTRODUCTION}

The modern concept of national security is a comprehensive concept, from the content point of view, many aspects of it including the territorial security, economic security, political security, military security, cultural security, technology security, ecological security. In a series of economic elements of security, energy security has become an important link in $[1,2]$. Energy security is the basic condition for people's daily life, in all walks of life and the modern civilization and progress, is an important foundation for the normal operation of the national economy, national security, effective protection of people's material and cultural living standards continued to improve and the national sustainable development strategy. Energy security is a major task facing the reality Chinese, but also realize the peaceful development strategy and the completion of Chinese "foundation of the Twelfth Five Year Plan" and the important guarantee. The current energy security research and education system is not comprehensive, is an important cause of the problem of energy security. Therefore, in order to strengthen the safety education imminent energy. In order to promote the domestic and foreign scholars on the China energy security issues in-depth discussions and exchanges, "Chinese in seven provinces and cities of college student concept of security" in the survey, respondents added about energy security issues.
In addition, it tries to find out the relationship between energy security and Chinese answer other main security problems from the sample group selection.

\section{THE HISTORICAL EVOLUTION OF ENERGY SE- CURITY}

After the first oil crisis, in American advocated the establishment of the International Energy Agency (IEA). This is a combined action of developed countries to ensure energy security, its purpose is to: members to take measures to control the distribution of oil, oil demand, in case of emergency, and the provisions of the petroleum member state compulsory reserves equivalent to 90 days of net imports. In twentieth Century 80 years, the security of supply for the traditional concept of energy security, the main starting point gradually moves towards a comprehensive energy security "(Comprehensive Energy Security) in the direction of development, energy security has been given more and more attention to the new connotation of the past. Only emphasize the security of energy supply, reduce the traditional concept of energy security dependence on imported energy is too narrow, unable to adapt to the demand of comprehensive security. In the pursuit of a sustainable development in the era of globalization, to break through the traditional concept of energy security, the establishment of a comprehensive concept of energy security has become an inevitable trend of the development of the national energy strategy. With the decline in global climate change the quality of atmospheric environment of warm, people have gradually reached a con- 
sensus on the issue of environmental protection and sustainable development. In 1993 Joseph Om for energy security environmental protection has increased to 90 years: the target of energy security with increasing economic competitiveness and reduce the deterioration of the environment, to ensure that adequate and reliable energy services. In 1997 the "Kyoto Protocol" marked a worldwide re defines the concept of energy security, the national energy development strategy, increases energy use is to deal with the ecological environment of human existence and development of the threat the requirements. Energy supply, economic competitiveness and environmental quality had become the three essential elements to ensure national energy security. In July 29, 2008, the United Nations Secretary General Ban Kimoon has called on the world to stop all hostilities in Beijing during the Olympic Games. In August 8, 2008, Beijing is the twenty-ninth session of the summer Olympic Games opening day, the outbreak of armed conflict between Russia and Georgia. Some media commented that behind the war between Russia and is American contest, but we should also see the energy behind the conflict. Since 8, the Russian troops entered Georgia's breakaway regions of South Ossetia and Georgia native Republic, occupied from the Georgian capital Tbilisi's city 47 miles (Gori). Centre for global energy studies in London (Center for Global Energy Studies, CGES senior analyst Ian Lee said Jul), only about two days of events showed the risks of foreign energy supply and the degree of fragmentation of the region and the region. Barclays Capital (Barclays Capital) head of commodities research and managing director of Paul Horsnell said, in spite of the Caspian Sea region contains a large number of hydrocarbon resources, Turkey BTC shootings and the Georgian war challenge means that it will never become a formal alternative to Middle East oil selection. In recent months, the market worried about concentrated between Iran and Western countries exacerbate tensions in the Persian Gulf, especially the unrest in the Strait of Hormuz blockades and risk of Nigeria Delta region continued. In contrast, many western countries and companies become more and more dependent on the Caucasus channel delivery of oil and natural gas.

\section{THE IMPORTANCE OF THE ISSUE OF ENERGY SECURITY}

Temporary interruption of a serious shortage of energy supply, and prices soared to a country's economic damage, mainly depends on the degree of dependence on: economic, energy prices, the international energy market, and strain capacity (including the strategic reserve, reserve capacity, alternative energy, energy efficiency, technical strength and so on). In order to ensure that the pay of energy supply price, namely the external cost, sometimes far exceed the energy price. For example, in order to ensure the supply of oil in the Middle East American invested huge amounts of the region's economic and military aid, the average expenditure of a barrel of crude oil costs about 3 times the market price of crude oil.

\subsection{Embodied Energy Security Problems}

The importance of the issue of energy security, not only for the performance between regions and countries, and the national energy resources distribution and utilization level is not balanced, and the resulting energy shortage problem (not absolute shortage of energy) and even war, also showed high accident rate of energy sources industry.

According to the occupation safety and Health Administration Department of labor USA (OSHA) database, during 1997 and 2003, American upstream oil and gas industry in each of the $10 \mathrm{~d}$ is a fatal accident occurred. Since entering the fast track of economic development, China's coal mine gas, water disaster is frequent, each producing one million tons of coal mine safety and the death of 4 people, every 7.4 D China problems occurred in coal mine accidents is much more the world public criticism, not just mine frequent loss of hundreds of lives, but also including Chinese national image; oil and gas production in the same situation is not optimistic, after the Chongqing Kai-Xian natural gas blowout accident following in China in 2003, according to the State Administration of production safety supervision and management of the report, in 2005, the petroleum and natural gas exploitation industry accident death toll to 25 people, an increase of $66.7 \%$. In recent years, Liaohe Oilfield Company such as shallow water explosion, refined oil pipeline accidents, Sinopec Shengli Oilfield platform tilt, Xinchang gas field blowout accident, Dalian Xingang 7-16, Nanjing residential area of explosion propylene leak explosion, once again the impact of energy safety accidents greatly beyond the technical and economic category.

Because of this, including USA, western developed countries have the energy security as an important part of the national security, and energy security as a key foreign policy objective. It can be said, for any one country, energy security has become an important field of security must examine with global vision, vision of the world, the future vision, vision of humanities. It has gone beyond the field of social production and become a matter of the well-being of people's lives, beyond the field of material and technology has become an important field of the construction of the harmonious society, beyond the scope of economic security has become an important part of national security, national security beyond the category and become a global security issues, beyond the reality of development in the world and has become a long-term problem is related to the future of human beings.

\subsection{Facing the Issues of Energy Security Challenges}

China is in the industrialization, urbanization accelerating period, higher energy consumption intensity. With the further expansion of economic scale, energy demand will continue to rapidly increase, the pressure of energy supply, the contradiction between supply and demand will exist for a long time, the degree of dependence on foreign oil and natural gas will be further improved.

\subsubsection{The Shortage of Resources}

Energy resources in our country are not small, but the per capita low. Resources exploration has lagged behind, the impact of energy production capacity increase. At the same time, our country's energy resources distribution is very uneven, large scale, long distance transportation of coal, resulting in tight capacity, cost increase, affecting the coordinated development of the energy industry. 


\subsubsection{The Structure of the Problem}

Coal is the basic energy of China, rich in coal, gas, oil is difficult to change the energy structure. China's coal clean utilization level is low, pollution from coal combustion. If this situation continues, it will bring greater pressure to the ecological environment.

\subsubsection{Backward Technology}

China's energy technology has made great progress, but there is a large gap compared with the requirements of the development of. Renewable energy, clean energy, alternative energy technology development is lagging behind, the application technology of energy saving and consumption reduction, pollution control is not widely, some equipment major energy technology independent design and manufacturing level is not high.

\subsubsection{International Influence}

The relative lack of petroleum and natural gas resources in China, based on the domestic production to supply at the same time, the expansion of international energy cooperation. But the global energy balance between supply and demand of petroleum market weakness, frequent fluctuations in international oil prices, high oscillation, non-economic factors also affect the international energy cooperation. This requires us to balance domestic development and international cooperation, improve energy security degree.

\subsection{China Now Faces the Challenge of Energy Security}

Chinese himself is a net importer of crude oil, is second only to American global second largest oil consuming country. Chinese energy consumption accounts for only about $8 \%$ of the total global demand, but the demand is the rapid expansion.

In 2006 April, President Hu Jintao at the end of China America visit, from 22 to 29 days after another visit to Saudi Arabia, Morocco, Nigeria, Kenya and other Middle East countries and Africa. In contrast, American is the world's largest oil consumer, the other four countries are large or small oil exporting country. In oil production since then Prime Minister Wen Jiabao visited countries also occupy a considerable proportion. These are fully illustrated the energy issue dominated by oil occupies the main content of the state's overall diplomacy.

In June 19, 2008, the European Union Chamber of Commerce in China Roundtable energy working group concluded that: in the sustainability of energy security and environment, Chinese government faces the largest, most difficult tests, including the rapid industrialization, urbanization and motorization process, how to satisfy the people to the environment quality requirements, to provide a variety of supply cheap, clean, convenient and feasible:

In the current international background of high oil prices, environmental pollution is very serious in the country and the urgent need to improve at the same time. How to face the question in the reduction of greenhouse gas emissions increasing international pressure? in the present international background, the domestic oil prices in line with international to a certain extent, but also take into account the impact on the economy. Due to the lack of strategic oil reserve capacity Chinese necessary for crude oil supply disruption, sudden and oil price fluctuations of strain ability is poor. With the future of the increase in the number of imported crude oil and the international market oil price fluctuations, the safety of imported oil resources urgent.

\section{THE DEFECTS OF EDUCATION CHINESE EN- ERGY SECURITY CONCEPT}

\subsection{Contemporary College Students are Lack of Aware- ness of Energy Security Concept}

Energy security consciousness of college students is relatively weak, even including the oil and other energy directly or indirectly related to the colleges and universities. At present, the university has no effective system of energy security from the education system, teachers, professional setting, course construction, teaching conditions, will lead to higher professional talents cultivation is not only the lack of overall energy security concept, strong sense of energy security, energy security and the lack of specific skills training, it is difficult to undertake lead the whole society attention and join the energy security responsibility. The realization of if things go on like this, will directly affect the national recycling economy, conservation oriented society, energy crisis, the construction of ecological civilization and harmonious society building goals.

\subsection{Energy Security Concept of Education Related De- fects}

The domestic and foreign research on the concept of energy security education for college students is very few, the author found that only to die in [3] thinking of college students in the new era of education on the concept of energy security and energy security of the college students' education is directly related to. Overall, the author thinks that the existing research results and the concept of energy security education related defects in the following aspects:

The existing research about energy security, analysis mostly focus on the technical point of view, the pure energy science academic relationship between supply and demand, according to energy production, transportation, storage, trade and development and utilization of new energy sources especially the safety technology of the upper stage of energy development and utilization of preventive measures, focus on research and Discussion on how to solve the balance the shortage of energy and the energy supply problem, seek the most security strategy of energy and technology, energy and economy, energy and diplomatic, political, rarely involved in energy and energy and culture, education, energy and energy security issues and the source of life, energy and environment, energy and health, energy and psychological aspects.

The existing research about energy security, adhering to the "great game" basic political point of view, starting from the perspective of competition, to stand on the position of narrow national interest and global challenges and human well-being, most of the monopoly and hegemony and non cooperation and win-win angle, not really to put forward to the effective strategy to ensure global energy security. 
The existing research is limited to the material interests of human energy security level, most of the energy security is an urgent need to solve the economic lifeblood, rarely from the Ideological Education (safety knowledge and safety skills training), personnel training, social stability, ecological protection (progressive changes in consumption concept, way of life) cultural innovation, the future of the nation, the non-material interests angle, carry out special study on energy safety education. Including education strategy, talent strategy, social strategy, culture strategy, psychological strategy, and energy security related to the study of soft power is still blank. These tasks, only fundamentally through to solve energy security education mode innovation.

The existing research about energy security education is lack of the research on energy security, not education allround development of all students, especially to the Petroleum Colleges and the country's future energy security is closely related to the college students in the new period, to the height of the global political thought education, a new mode of energy security education the whole process, allround, three-dimensional and people-oriented.

\section{COUNTERMEASURES OF INNOVATION OF CHINA'S ENERGY SECURITY EDUCATION OF COLLEGE STUDENTS}

Human beings have the energy crisis and energy accidents are not due to energy shortages caused by hand, but because of the resources and capital people endless chasing of material interests and their own desires without. The energy production, transportation, storage, processing, trade and consumption of the accident, the vast majority are not because of science and technology and material equipment backwardness, largely because of the defects of the system design and the artificial errors caused by. Visible, regardless of how changes in the social system, the productive elements in [4-6], the revolutionary role still human.

To effectively solve the future energy security problems, there must also come back to the quality of education and human. That is to say, if the results from the energy security of existing research to find out the countermeasures to ensure energy security, is tantamount to asking for the impossible. Oil is a new energy security concept education of college students on China's economic security, national security, social stability and sustainable development are important, I believe that from the following 3 aspects of innovation of college students education of petroleum energy security $[7,8]$.

\subsection{The Concept of Energy Security, Education and the Combination of Ideological and Political Education}

As the market economy is the existence of one-sided pursuit of utilitarian tendency to rely on science and technology, instrumentalism, easy to people's pursuit to materialism. Only with good moral culture of people, will be highly patriotic enthusiasm, will include energy security to pay attention to the national security, will have a sense of urgency, a sense of pressure and responsibility. Therefore, the need to strengthen the oil and ideological and political education of college students, the concept of energy security, education and the combination of Ideological and political education, to instill play the function of Ideological and political education, navigation, change function, regulating function, cohesive function, economic function, culture function, ecological function.

\subsection{The Education of Humanistic Spirit and Scientific Spirit Education Combination}

The scientific spirit and humanistic spirit of dialectical unity, both through the science inquiry and thinking process, is the essence of human practice. The former criterion based, pursuit of truth, respected rationalism, non restricted exploration; the latter takes the human as the center, the pursuit of a better, must know a taboo.

The economic and social progress is not only a group of quantitative indicators, more important is the all-round development of people, the scientific spirit and humanistic spirit throughout the "three steps to walk" the strategic target of the pursuit. If a social material wealth and spiritual poverty in sharp contrast, people will generally lack the scientific thought and humanistic thought, then, cannot conceive of the realization of the "four modernizations", not sure if this life is what the people need of modern life. Therefore, on the one hand, strengthen the scientific spirit of college students education, enhance the ability to know and transform the nature of college students, in order to promote the development of social productive forces; on the other hand, should also pay attention to the humanistic spirit of college students education, advocate the new concept of energy security, education and the sciences and humanities, manmachine combination, mutually beneficial cooperation, diversified development and coordinated protection and harmonious symbiosis.

\subsection{Combining the Concept of Energy Security, Educa- tion and Professional Education}

To achieve energy security strategy requires students to have a correct understanding of the science of energy security, and the effective integration of scientific knowledge, depends on the education resources. Colleges and universities should be energy security strategy implementation departments first-line managers to enrich the teachers in their school, when compared with professional teachers working, more help to students about energy security strategy of scientific knowledge.

The combination of professional education of the concept of energy security education and Petroleum University, break through the traditional only from engineering, political science, economics is the study of the field of energy security and energy security concept education limitations, from the perspective of political science, engineering, economics, education, management science, sociology, psychology and other disciplines, the establishment of oil college students' concept of energy security education new ideas, new models, new goals, new contents and new methods.

\section{CONCLUSION}

The energy security in the education system, to enable students to have a scientific cognition on energy security, 
cultivate the right concept of energy security, strengthen the sense of hardship, is conducive to the improvement of College Students' comprehensive qualities. The author thinks that absorb and learn from the research results of the related disciplines, the university education closely related to energy security, in-depth analysis of the importance of energy safety education, put forward the system of the energy security theory of education, is conducive to the correct concept of energy security culture, arouse the students' thinking, to enhance its energy security awareness. As a highly educated, high-quality group of college students, after graduation to work in enterprises and government departments, has the sense of energy security, the basic knowledge and skills of energy security, can effect predict and control the unsafe factors, ready for the international and domestic environment, enhance the ability to prevent risks.

\section{CONFLICT OF INTEREST}

The authors confirm that this article content has no conflict of interest.

\section{ACKNOWLEDGEMENTS}

Declared none.

\section{REFERENCES}

[1] Ge Dong Sheng on National Security Strategy, Military Science Press, Beijing, 2006.

[2] D.T. Huang, G. Clermont, L. Kong, L.A. Weissfeld, J.B. Sexton, K.M. Rowan, and D.C. Angus, "Intensive care unit safety culture and outcomes: a US multicenter study," International Journal for Quality in Health Care, vol. 22, no. 3, pp. 151-161, 2010.

[3] G. Ladson-Billings, "From the achievement gap to the education debt: Understanding achievement in US schools," Educational Researcher, vol. 35 , no. 7, pp. 3-12, 2006.

[4] R.M. Grant, "The resource-based theory of competitive advantage: implications for strategy formulation," Knowledge and strategy, vol. 33, no. 3, pp. 3-23, 1991.

[5] W. Zhang, Y. Zhou, "Contemporary college students' National Security Education," Journal of Jiangnan Social Sciences, vol. 9, no. 4, pp. 74, 2007.

[6] "Research Center of economic security Chinese Institute of contemporary international relations," The global energy big game (M). Current Affairs Press, Beijing, 2005.

[7] X. Li, "Southwest Petroleum University Education Teaching Research and Practice," Petroleum Industry Press, Beijing, 2008.

[8] H. Liu, and Y. Xiao, "The new conception of national security (J) on the cultivation of national consciousness of college students from the perspective of higher education," The Coal, vol. 27, no. 5, pp. $88,2009$.

(c) Zhang et al.; Licensee Bentham Open.

This is an open access article licensed under the terms of the (https://creativecommons.org/licenses/by/4.0/legalcode), which permits unrestricted, noncommercial use, distribution and reproduction in any medium, provided the work is properly cited. 